spectrum of the comet, including some taken with a calcite-quartz spectrograph, which show new radiations and will enable better wave-length values to be determined; the conclusions published in the first note are to be looked upon as only provisional.

Observations of the Surfaces of Jupiter's Principal Satellites and of Titan.-During the 1907-8 opposition of Jupiter, M. J. Comas Solá continued his observations of the principal Jovian satellites, and now publishes his results, with drawings of J iii. and iv., in No. 4290 of the Astronomische Nachrichten (p. 290, December II).

Satellite i. appears to be definitely ellipsoidal, the flattening amounting to as much as one-fifth of the major axis. The direction of the longest axis is not, according to M. Solá's observations, parallel to that of Jupiter's bands, but has a position-angle some $28^{\circ}$ greater than that of the bands.

With most other 'observers, M. Sola finds that the second satellite always appears round.

The observations of J iii. are given in detail, and many features on the satellite's surface noted. Among these, white polar caps, varying in intensity and size from time to time, equatorial bands, and shadowy areas were observed, and, from the varying appearance of the latter it would appear that the effects of the satellite's rotation were seen.

Satellite iv. presented no feature which could be seen definitely, with the exception of a very faint north polar cap on December 24, 1907 , but several were suspected from time to time.

The observations of Titan indicate that this member of the Saturnian family has a more or less dense atmosphere, for the limbs were always dark and difficult to see, whilst towards the centre of the disc lighter patches were visible. The drawing for August 13, 1907, shows two of these patches having the appearance of a very diffuse double star.

Corrections of the Position and Diameter of MERcury.-From observations of the contacts during the transit of Mercury on November 13-14, I907, Prof. Stroobant has deduced corrections for the position and diameter of the planet, and publishes the results in part i., vol. xii., of the Annales astronomiques de l'Observatoire royal de Belgique.

The observations were made at thirty-three observatories in different localities in Europe, South Africa, and the United States, and their discussion leads to the following results:- Instead of the diameter being $6^{\prime \prime} \cdot 6 \mathrm{r}$, at unit distance, as usually accepted, it is $6^{\prime \prime} .16$, and, consequently, the actual radius, taking the equatorial radius of the earth as $6378 \mathrm{~km}$., is $2232 \mathrm{~km}$. From this it follows that, as compared with that of the earth, the volume of Mercury is 0.043 instead of 0.052 , whilst the density is $\mathrm{I} .42$ instead of $\mathrm{I} \cdot \mathrm{I} 7$, if the accepted value for the mass be retained. The corrections to the position of the planet in the equatorial coordinates are $\Delta \alpha=+0.066 \mathrm{~s}$. and $\Delta \delta=-0^{\prime \prime} \cdot 22$, and in the ecliptic coordinates $+0^{\prime \prime} .97$ and $+0^{\prime \prime} .04$ in longitude and latitude respectively.

The South Polar Cap of Mars.-Bulletin No. 35 of the Lowell Observatory contains Prof. Lowell's measures, made from drawings, of the size of the south polar cap of Mars between March 22 and November 13, 1007.

The tabulated results give the history of the cap for about eight of our months, from about its maximum to near its minimum area, and show that its size decreased regularly from about 0.388 of a hemisphere to 0.002 .

The "Companion to the Observatory."-This useful annual, published by Messrs. Taylor and Francis at xs. $6 d$., contains the usual data and ephemerides for the observations of the sun, planets, eclipses, satellites, variable and double stars, \&c.

Mr. Denning has revised the meteor notes, Mr. Maw has supplied a number of observations of double stars, and M. Baillaud has furnished advance proofs of the Annuaire du Bureau des Longitudes from which the list of Algol variables has been copied.

A useful list of the standard times of various countries using the Greenwich meridian is given on p. 32, and from the tablc of the magnetic elements for Greenwich Observa- tory we see that the "inferred" values for 1909 are :declination, $15^{\circ} 50^{\prime} \mathrm{W}$.; horizontal force, 0.1854 ; dip, $66^{\circ} 55^{\prime}$.

The Nizamiah Observatory at Haidarabad.-The establishment by his Highness the Nizam of Haidarabad of a well-equipped astronomical observatory in his dominions is referred to in the Times of December 17 . The equipment includes, besides the purely astronomical and meteorological instruments, a very complete photographic department and extensive workshops fitted with modern tools and appliances for both wood and metal working.

\section{PRIZE SUBJECTS PROPOSED BY THE FRENCH ACADEMY OF SCIENCES FOR THE YEAR I9Io.}

GEOMETRY.-The grand prize of the mathematical sciences (3000 francs). The problem of finding all the systems of two meromorphic functions in the plane of a complex variable and connected by an algebraic relation is known. The analogous question is suggested for a system of three uniform functions of two complex variables, having everywhere at a finite distance the character of a rational function and connected by an algebraic relation. In default of a complete solution of the problem, to indicate examples leading to classes of new transcendental functions. The Francour prize (rooo francs), for work in pure or applied mathematics; the Poncelet prize (2000 francs), for a work on pure mathematics.

Mechanics.-A Montyon prize (70o francs), for inventing or improving instruments useful to the progress of agriculture, the mechanical arts, or sciences; the Fourneyron prize (Iooo francs), for an experimental and theoretical study of the effects of shocks of a hydraulic ram in elastic tubes.

Navigation.-The extraordinary prize of 6000 francs, for work tending to increase the efficiency of the French naval forces; the Plumey prize (4000 francs), for improvements in steam engines or any other invention contributing to the progress of steam navigation.

Astronomy.-Pierre Guzman prize (100,000 francs), for the discovery of a means of communicating with any planet other than Mars, or, failing this, the interest will be awarded for work leading to progress in astronomy; the Lalande prize ( 540 francs); the Valz prize ( 460 francs) the Janssen prize, for an important progress in astronomical physics.

Geography.-The Tchihatchef prize (3000 francs), for Asiatic exploration; the Binoux prize (2000 francs), for work on geography or navigation; the DelalandeGuérineau prize (Iooo francs); the Gay prize (I 500 francs), for zoological and anthropological researches in South America, especially in the region of the Andes.

Physics.--The Hébert prize (rooo francs), for a discovery in electricity of practical or industrial use; the Hughes prize (2500 francs); the Kastner-Boursault prize (2000 francs), for the best work on the application of electricity in the arts, industry, or commerce.

Chemistry.--The Jecker prize (1о, ooo francs), for work in organic chemistry; the Cahours prize ( 3000 francs), for the encouragement of young chemists; Montyon prizes (unhealthy trades) (2500 francs and a mention of 1500 francs), for improving the hygienic conditions of an unhealthy trade or calling; the Berthelot prize (500 francs) the Alhumbert prize (rooo francs), for an experimental study of the electrical properties of the metallic alloys.

Mineralogy and Geology.-The Delesse prize (I 400 francs).

Botany.-The Desmazieres prize ( 1600 francs), for a memoir on cryptogams; the Montagne prize (I 500 francs), for work on the anatomy, physiology, development, or description of the lower cryptogams; the de Coincy prize (9oo francs), for a work on phanerogams; the de la FonsMelicocq prize ( 900 francs), for a work dealing with the botany of the north of France; the Bordin prize (3000 francs), for a study of the origin, development, and disappearance of the transitory tissues which may enter at various periods into the structure of the vascular plant. 
To determine, in each particular case, the ephemeral rôle of the tissue considered.

Anatomy and Zoology.-The Savigny prize (I50o francs), for the assistance of young travelling zoologists, not in receipt of Government assistance, and who specially occupy themselves with the invertebrate animals of Egypt and Syria; the Thore prize (200 francs), for the best work on the habits and anatomy of one species of European insect.

Medicine and Surgery.-A Montyon prize (2500 francs and mentions of 1500 francs), for a discovery useful in medicine; the Barbier prize (2000 francs), for a discovery of value to medical, surgical or pharmaceutical science, or botany in relation to medicine; the Bréant prize (100,000 francs), for the discovery of a cure for Asiatic cholera or the definite cause of this disease. If the prize is not awarded, the interest will be given for researches bearing on cholera or other epidemic disease. The Godard prize (rooo francs), for the best memoir on the anatomy, physiology, and pathology of the urinogenitary organs; the Baron Larrey prize (750 francs), for a work treating of military medicine, surgery, or hygiene; the Bellion prize (I 400 francs); the Mège prize (I0,000 francs); the Dusgate prize (2500 francs), for the best memoir on the diagnostic signs of death and on the best means of preventing premature burial.

Physiology. - A Montyon prize (750 francs), for a work on experimental physiology; the Philipeaux prize (900 francs), for the same; the Lallemand prize (I80o francs), for works relating to the nervous system; the MartinDamourette prize ( 1400 francs), for a work on therapeutical physiology; the Pourat prize (I000 francs), for a memoir on the action exercised by the X-rays and the radium rays on the development and nutrition of living cells.

Statistics.-A Montyon prize (Iooo francs, and a mention of 500 francs), for the most useful work dealing with statistics.

History of Science.-The Binoux prize (2000 francs).

General Prizes.-These include the Arago, Lavoisier, and Berthelot medals; the Gegner prize (3800 francs); the Lannelongue prize (2000 francs); the Trémont prize (I 100 francs); the Wilde prizes (one of 4000 francs and two of 2000 francs), for discoveries in astronomy, physics, chemistry, mineralogy, geology, or experimental mechanics; the Lonchampt prize (400o francs); the Saintour prize (3000 francs); the Victor Raulin prize (I 500 francs), for a work on the meteorology and physics of the globe; the prize founded by Mme. la Marquise de Laplace; the Félix Rivot prize (2500 francs); the Leconte prize (50,000 francs), for important discoveries in mathematics, physics, chemistry, natural history, or medicine; the Houllevigue prize 5000 francs); the Caméré prize (4000 francs); the Jérome Ponti prize (3500 francs).

Of these, the Pierre Guzman, Lalande, Tchihatchef, Delesse, Desmazières, and Leconte prizes are expressly stated to be offered with preference of nationality.

\section{CHEMICAL RESEARCH AT THE UNIVERSITY OF MANCHESTER.}

THE chemical schools at the University of Manchester, probably already the largest in the kingdom, are being enlarged by the addition of a new block of buildings at a cost of about 20,000 . Already considerable progress has been made with the building operations, and it is hoped that the new block will be ready for opening in the early autumn of 1909 . The chief addition will be a new large laboratory having accommodation for forty students, and fifteen smaller research laboratories.

The following description of the objects of the new buildings is taken from a recent interview with Prof. W. H. Perkin, published in the Manchester Guardian. He considers that the loss of the coal-tar industry to this country was due, not only to the manufacturers not realising the importance of employing chemists and carrying out research work, but also to the universities, which were very greatly to blame. Organic chemistry was hardly taught at our universities, and such laboratories as they possessed were poor and ill-equipped. As a consequence, if manufacturers did require chemists they could not obtain them.
It was in 1874 that the original coal-tar colour works at Greenford Green, near Harrow, were sold. The reason for giving up the works was partly owing to the natura dislike for an industrial career of the late Sir William Perkin and his desire to devote himself entirely to research chemistry; but it was also because he recognised that the works could not be satisfactorily carried on and be able to compete successfully with the rising industry in Germany unless he took into the works a large number of research chemists, as the Germans had done. But although inquiries were made at many of the British universities in the hope of finding young men trained in methods of organic chemistry, such men were not forthcoming.

The older universities at that time scarcely recognised organic chemistry; it is doubtful whether they thoroughly appreciated chemistry at all. The newer universities, which at present are doing such good work and of which we are justly proud, had not come into existence. Prof. Perkin said he was strongly of the opinion that the manufacturer of organic products during $1870-1880$ was, owing to this neglect of organic chemistry by our universities, placed in a very difficult and practically impossible position.

But, in the meantime, organic chemistry had taken root in Germany, and great schools devoted to this branch of chemical science had been founded. History tells us how the German manufacturers made use of the young chemists who had been trained in these laboratories. Consequently, the works in Germany increased in size and in number, and obtained the world's trade in organic chemicals. Had our universities at this time pursued the same principle, in all probability the coal-tar colour and allied industries would not have been lost; but now this state of things has changed, and "I am convinced that failure on the part of the manufacturers to develop any industry connected with organic chemistry is no longer due to the impossibility of obtaining the services of young chemists of ability.'

The scheme which it is hoped to develop in connection with the Manchester Chemical School is laid on the lines which have been found so valuable abroad. Two lines of procedure are open to the manufacturer.

$\mathrm{He}$ may send his sons to the university, and as soon as they have passed through the honours B.Sc. course, and have thus received a thoroughly sound general training, they will be fit to engage in research work dealing with problems of a technical nature, either suggested by the university professors or by the manufacturers. Such a course, extending over two or more years, will be the best preparation for an industrial career.

Another way in which the manufacturers can be helped if they wish to solve a difficult problem or invent some new process is to place at their disposal one of the smaller research rooms. In this room his own research chemist from the works can, under the best conditions, investigate the problem, either alone or with assistance from the university staff. If he happens to have no research chemist available for the purpose, one of the university graduates can be engaged to work under the professor's superintendence.

The University will, however, not open its doors to do purely routine analysis, ordinary commercial work, or patent litigation. It lays itself out to train research chemists or help by research work, and in this direction alone.

\section{WATERS AND GLACIERS.}

UNDERGROUND waters play a considerable part in recent researches on French caves (Spelunca, tome vii., 1907-8, Nos. 47-52). M. Fournier's observations in the Jura (Nos. 47 and 50 ) are largely concerned with following out the courses of streams that are used for household purposes. He agrees with $M$. Martel that springs may be regarded with suspicion when their temperature varies by even $\mathrm{I}^{\circ} \mathrm{C}$. from that of water in the same region which is known to come from considerable depths. A number of caves in various levels of Jurassic limestone are drawn in plan and section, and the continuity of certain streams has been proved by the use 